\title{
Multifunctional Porous Concrete Urban Pavements for a More Sustainable and Resilient Future ${ }^{+}$
}

\author{
Eduardo-Javier Elizondo-Martínez ${ }^{1, *}$, Valerio-Carlos Andrés-Valeri ${ }^{2}$, Luis Juli-Gándara ${ }^{3}$ and \\ Jorge Rodríguez-Hernández ${ }^{1}$ \\ 1 GITECO Research Group, Department of Transports, Projects and Process Technology, Civil Engineering \\ School, Universidad de Cantabria, 39005 Santander, Spain; jorge.rodriguez@unican.es \\ 2 Institute of Civil Works, Faculty of Engineering Sciences, Universidad Austral de Chile (UACh), \\ Campus Miraflores, 2060 Valdivia, Chile; valerio.andres@uach.cl \\ 3 GCS Research Group, Department of Transports, Projects and Process Technology, Civil Engineering \\ School, Universidad de Cantabria, 39005 Santander, Spain; luis.juli@alumnos.unican.es \\ * Correspondence: eduardo-javier.elizondo@alumnos.unican.es; Tel.: +34-942203943 \\ + Presented at the 2nd International Research Conference on Sustainable Energy, Engineering, Materials and \\ Environment (IRCSEEME), Mieres, Spain, 25-27 July 2018.
}

Published: 14 November 2018

\begin{abstract}
Many cities around the world are handling many problems derived from urbanization, resulting in an uncontrolled growth of cities. Moreover, Climate Change effects are affecting all countries and specially cities. In this context, urban drainage and paving strategies demand a bigger economical investment to avoid a great impact in citizens quality of life, and in the environment. The main objective of this research is to contribute, in an innovative way, with the construction of concrete urban pavements by studying, quantifying and trying to join together a series of characteristics and benefits that are analyzed nowadays, but in a separately way. Trying to achieve an integrated pavement, with resilient properties (adapted to Climate Change) and more sustainable (economically, socially and environmentally).
\end{abstract}

Keywords: porous concrete; Porous Pavement; resilience; infiltration; photocatalysis; cool city; indirect tensile strength

\section{Introduction}

Porous pavements (PP) have been told to be one of the best solutions to minimize the impact of Climate Change, caused, mainly, because of human activities like the urbanization around the world. They are a special type of pavement that lets water to percolate into the ground, allowing to refill the underground aquifers or catching it for future uses [1-3]. Among PP, porous concrete pavements (PC) have become of great interest due to many advantages they present, allowing to obtain an integrated pavement that becomes more sustainable economically, socially and environmentally. In addition, a pavement with resilient properties, that can be adapted to climate change. The coarse aggregate gradation used for PC leads to a higher amount of air voids (AV), around $15-30 \%$. Allowing infiltration [4-13]. The binder is made of a cementitious paste, integrated mainly by cement, water and, in some cases, fine aggregate (sand) [14,15].

Additives are added in order to enhance the mixtures in terms of mechanical capacity [16,17], which is low because the lack of fine aggregate. According to the literature reviewed, additives may decrease the infiltration capacity of the samples, and even some authors revealed that additions (silica fume, fly ash) decrease the mechanical properties when certain amount is surpassed [18]. In order to obtain a trustworthy PC pavement, mixtures have to be reinforced with additives to achieve 
high mechanical properties. Being careful not to decrease the hydraulical capacity due to the adding of new materials.

The main purpose of this work is to study and join a series of characteristics PC can have, but have been studied separately so far. Properties that enables it to become multifunctional, besides the hydraulic properties mentioned before: Removal of air pollutants through photocatalysis $[19,20]$, temperature mitigation through a process of cooling cities [21,22], decreasing sound absorption generated by the interaction of wheels and pavement [23], and increasing road safety by heighten skid resistance in roads $[24,25]$.

\section{Pavement Design}

The research begins with the study and optimization of PC pavements, as well as their procedure and dosages in terms of their mechanical and hydraulic capacity. This section is divided in two areas. The first one, where a new methodology is created based on the ACI 522R-10 normative (Named DCP-Diseño de Concreto Poroso-for its acronym in Spanish), with the main difference of calculating the addition of fine aggregate (sand) into the cement paste, separating it from the aggregate amount, if sand is used, making a mortar. The second area, with an extensive literature review, dosage parameters were found, where the values design for different PC samples were stablished in order to evaluate the best behaviors. The main parameters considered were the water-cement ratio $(\mathrm{w} / \mathrm{c})$, sand-cement ratio $(\mathrm{s} / \mathrm{c})$ and the $\mathrm{AV}$ obtained. In addition, four different coarse aggregate gradations (AG) were tested: $2-4 \mathrm{~mm}, 4-8 \mathrm{~mm}, 4-12 \mathrm{~mm}$, and 8-12 mm. Also, two aggregate porosities were obtained $(44.30 \%$ and $47.00 \%)$ due to different compactions when calculating aggregate's density. Finally, some mixtures had manually cement amounts added, varying their AV. Table 1 represents the main parameters reviewed and used for designing PC mixtures and Table 2 shows the parameters found in the literature reviewed for each component in PC $[5,6,8-11,26]$.

Table 1. Main PC parameters for design.

\begin{tabular}{cccc}
\hline & w/c & s/c & AV \\
\hline \multirow{2}{*}{ Literature reviewed parameters } & Min: 0.20 & Min: 0.00 & Min: 13.00\% \\
& Max: 0.42 & Max: 0.43 & Max: 42.00\% \\
\hline \multirow{2}{*}{ Design ratios used } & 0.30 & 0.00 & \\
& 0.35 & 0.50 & $20.00 \%$ \\
\hline
\end{tabular}

Table 2. PC components parameters found in literature.

\begin{tabular}{ccccc}
\hline & $\begin{array}{c}\text { Cementitious } \\
\text { Material }\left(\mathbf{k g} / \mathbf{m}^{3}\right)\end{array}$ & Water $\left(\mathbf{k g} / \mathbf{m}^{3}\right)$ & $\begin{array}{c}\text { Coarse Aggregate } \\
\left(\mathbf{k g} / \mathbf{m}^{3}\right)\end{array}$ & Sand $\left(\mathbf{k g} / \mathbf{m}^{3}\right)$ \\
\hline Min & 150.00 & 50.00 & 565.00 & 0.00 \\
Max & 560.00 & 181.00 & 2035.20 & 146.00 \\
\hline
\end{tabular}

Three mixtures with the DCP and the ACI 522R-10 normative were made in order to compare both methodologies, employing the same $\mathrm{w} / \mathrm{c}$ ratio $(0.40)$ and three $\mathrm{s} / \mathrm{c}$ ratios $(0.00,0.50$ and 1.00). Where mechanical properties represented around a 30\% improvement for DCP mixtures, but infiltration was around $40 \%$ higher in the ACI 522R-10 mixtures. Nevertheless, infiltration in DCP mixtures was acceptable, with $11.79 \mathrm{~mm} / \mathrm{s}$ as the lowest result (for s/c of 0.50 ).

\section{Statistical Analysis}

With the use of the software Minitab 17, where a response surface design was created by introducing the variables (parameters) in order to obtain the optimal mixtures to elaborate. A set of 38 different mixtures (from 144 possible) was decided to elaborate, according to the scheme in Figure 1, with the purpose of evaluating the best dosage behavior in order to implement additives and additions later, and assess the improvements obtained in terms of multifunctionality in PC. 
The Indirect Tensile (IT) test was used to evaluate the mechanical capacity of the samples, employing the equipment and equations of Normative UNE-EN 12390-6 (Test and equations description) and EN 12390-1 (machine description). Permeability was measured with a falling head permeameter adapted to cylindrical specimens as seen in Figure 2.

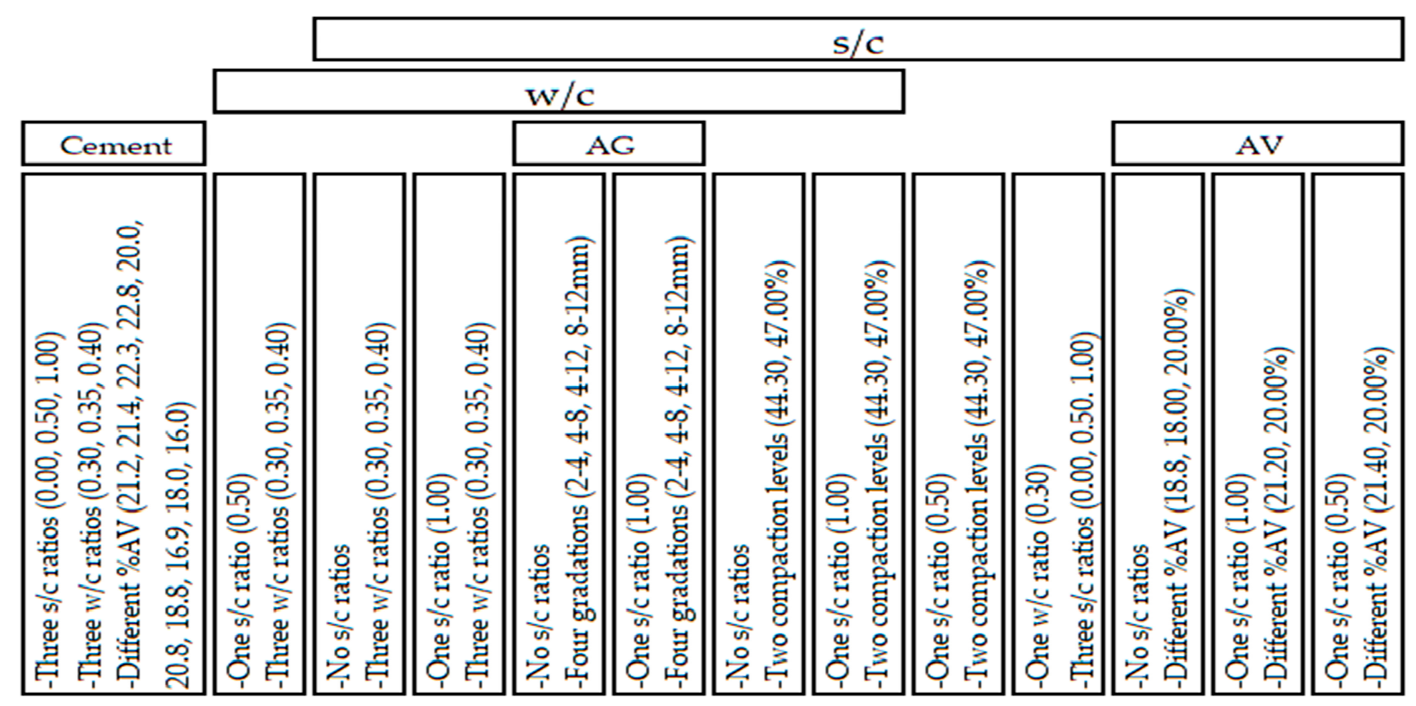

Figure 1. Scheme of PC mixtures comparison.

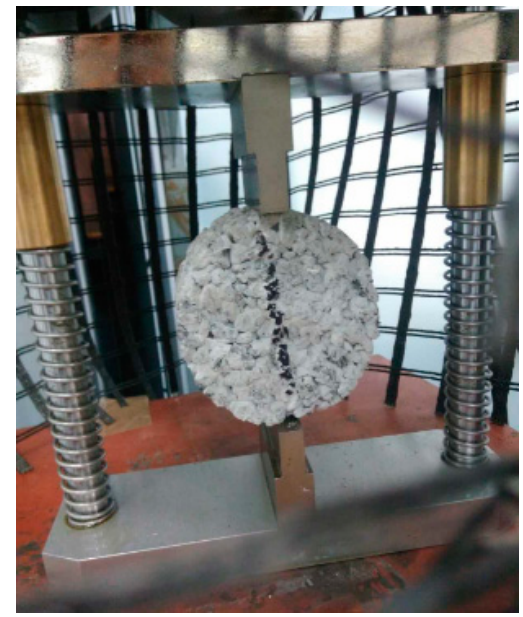

(a)

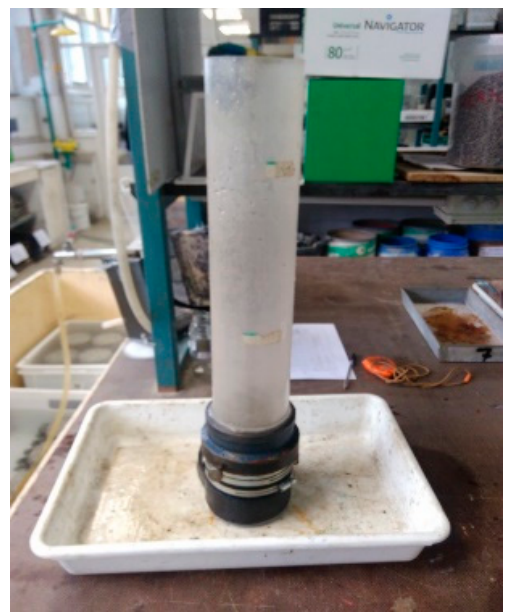

(b)

Figure 2. Tests for evaluating PC samples: (a) IT test; (b) Falling head permeameter.

To evaluate the best behaviors and parameters for an optimum PC mixture, the Analytic Network Process (ANP) statistical method was employed. Derived from the Analytic Hierarchy Process (AHP), making a pairwise comparison in order to decide the best mixture parameters and design, combining the mechanical and hydraulic factors [27,28]. Table 3 shows the top five PC mixtures according to the statistical analysis.

Table 3. Best five PC mixtures according to ANP method.

\begin{tabular}{ccccccc}
\hline Mixture & w/c & s/c & AG (mm) & AV Design & IT (Mpa) & Infiltration (cm/s) \\
\hline 3-1-1 & 0.40 & 1.00 & $8-12$ & $20.00 \%$ & 0.91 & 1.92 \\
1-2-2M & 0.35 & 0.50 & $4-8$ & $20.00 \%$ & 1.74 & 0.74 \\
1-2-3M2 & 0.30 & 0.50 & $4-8$ & $20.00 \%$ & 1.89 & 0.3 \\
1-2-1M2 & 0.40 & 0.50 & $4-8$ & $20.00 \%$ & 1.83 & 0.46 \\
R3-3 & 0.40 & 0.00 & $8-12$ & $20.00 \%$ & 1.14 & 1.32 \\
\hline
\end{tabular}


Behaviors were as normally expected, as mechanical properties decreseases while AV increseases, and viceversa for infiltration capacity, except for some cases. With this, the optimal proportion was obtained as shown in Table 4 . Where the results represent the best balanced mechanical-hydraulical relation.

Table 4. Optimal proportions for a PC mixture.

\begin{tabular}{cccccc}
\hline w/c & s/c & AG (mm) & AV Design & IT (Mpa) & Infiltration (cm/s) \\
\hline 0.40 & 0.50 & $4-8$ & $20.00 \%$ & 1.47 & 0.93 \\
\hline
\end{tabular}

\section{Conclusions and Next Steps}

The new methodology helped obtained good results, where adding sand to mixtures helped to improve the mechanical capacity while maintaining a reasonable AV content and good permeability. A balanced between the sand amount and the w/c ratio should be established in order to accomplish good results, as both a lack of materials and too much of it, tend to affect the properties.

Next steps will be the addition of additives, starting with an extended review of the literature. The main additives and additions used in PC mixtures are being located, as well as the optimal amount used by the authors to achieve the highest mechanical results as possible $[13,29,30]$. In addition, it is being evaluated the use of polymers to substitute the cement, obtaining a more environmental and strong mixture. Additionally, photocatalytic compounds are to be aggregated and evaluated in order to improve air quality of cities.

Author Contributions: E.-J.E.-M. and V.-C.A.-V. conceived and designed the experiments; E.-J.E.-M. and L.J.-G. performed the experiments; E.-J.E.-M. and V.-C.A.-V. analyzed the data; J.R.-H. contributed with the materials and analysis tools; E.-J.E.-M. wrote the paper; J.R.-H. and V.-C.A.-V. validated the analysis and lead the discussion and final conclusions.

Acknowledgments: This study was funded by the Spanish Ministry of Economy and Competitiveness and the European Union (ERDF) through the projects SUPRIS.SUReS (Ref. BIA2015-65240-C2-1-R) and SUPRIS-SUPel (Ref. BIA2015-65240-C2-2-R). The authors would like to thank Grupo Cementos Portland Valderrivas and BASF Construction Chemicals España S.L. for providing the cement material and additives, respectively, used in the investigation.

Conflicts of Interest: The authors declare no conflict of interest.

\section{References}

1. Rodrigues, J.; Hernandez, J.; Gómez-Ullate, E.; Fresno, D. Sistemas Urbanos de Drenaje Sostenible, Esc. Caminos, Canales y Puertos Santander; Universidad de Cantabria: Santander, Spain, 2011; pp. 1-25.

2. Perales-Momparler, S.; Andrés-Doménech, I.; Escalante, E. Los Sistemas Urbanos de Drenaje Sostenible (SUDS) en la Hidrogeología Urbana, Grup. In Proceedings of the TRAGSA Madrid IX Simposio de Hidrogeología AIH, Elche, Spain, 29-31 January 2008; pp. 1-12. Available online: http://www.dina-mar.es/ pdf/6-if-suds-2.pdf (accessed on 14 March 2018).

3. Lian, C.; Zhuge, Y. Optimum mix design of enhanced permeable concrete-An experimental investigation. Constr. Build. Mater. 2010, 24, 2664-2671, doi:10.1016/j.conbuildmat.2010.04.057.

4. Lim, E.; Tan, K.; Fwa, T. Effect of Mix Proportion on Strength and Permeability of Pervious Concrete for Use in Pavement. J. East. Asia Soc. Transp. Stud. 2013, 10, 1565-1575.

5. Rangelov, M.; Nassiri, S.; Haselbach, L.; Englund, K. Using carbon fiber composites for reinforcing pervious concrete. Constr. Build. Mater. 2016, 126, 875-885, doi:10.1016/j.conbuildmat.2016.06.035.

6. Brake, N.A.; Allahdadi, H.; Adam, F. Flexural strength and fracture size effects of pervious concrete. Constr. Build. Mater. 2016, 113, 536-543, doi:10.1016/j.conbuildmat.2016.03.045.

7. Jang, J.G.; Ahn, Y.B.; Souri, H.; Lee, H.K. A novel eco-friendly porous concrete fabricated with coal ash and geopolymeric binder: Heavy metal leaching characteristics and compressive strength. Constr. Build. Mater. 2015, 79, 173-181, doi:10.1016/j.conbuildmat.2015.01.058.

8. Giustozzi, F. Polymer-modified pervious concrete for durable and sustainable transportation infrastructures. Constr. Build. Mater. 2016, 111, 502-512, doi:10.1016/j.conbuildmat.2016.02.136. 
9. Bonicelli, A.; Arguelles, G.M.; Pumarejo, L.G.F. Improving Pervious Concrete Pavements for Achieving More Sustainable Urban Roads. Procedia Eng. 2016, 161, 1568-1573, doi:10.1016/j.proeng.2016.08.628.

10. Khankhaje, E.; Salim, M.R.; Mirza, J.; Hussin, M.W.; Rafieizonooz, M. Properties of sustainable lightweight pervious concrete containing oil palm kernel shell as coarse aggregate. Constr. Build. Mater. 2016, 126, 1054-1065, doi:10.1016/j.conbuildmat.2016.09.010.

11. Torres, A.; Hu, J.; Ramos, A. The effect of the cementitious paste thickness on the performance of pervious concrete. Constr. Build. Mater. 2015, 95, 850-859, doi:10.1016/j.conbuildmat.2015.07.187.

12. Zaetang, Y.; Wongsa, A.; Sata, V.; Chindaprasirt, P. Use of lightweight aggregates in pervious concrete. Constr. Build. Mater. 2013, 48, 585-591, doi:10.1016/j.conbuildmat.2013.07.077.

13. Lee, M.; Huang, Y.; Chang, T.; Pao, C. Experimental Study of Pervious Concrete Pavement. In Proceedings of the GeoHunan International Conference 2011, Hunan, China, 9-11 June 2011; pp. 93-99, doi:10.1061/47629(408)12.

14. Tennis, P.D.; Leming, M.L.; Akers, D.J. Pervious Concrete Pavements. 2004. Available online: http://myscmap.sc.gov/marine/NERR/pdf/PerviousConcrete_pavements.pdf (accessed on 22 March 2018).

15. Ngohpok, C.; Sata, V.; Satiennam, T.; Klungboonkrong, P.; Chindaprasirt, P. Mechanical properties, thermal conductivity, and sound absorption of pervious concrete containing recycled concrete and bottom ash aggregates. KSCE J. Civ. Eng. 2018, 22, 1369-1376, doi:10.1007/s12205-017-0144-6.

16. Martin, W.D.; Kaye, N.B.; Putman, B.J. Impact of vertical porosity distribution on the permeability of pervious concrete. Constr. Build. Mater. 2014, 59, 78-84, doi:10.1016/j.conbuildmat.2014.02.034.

17. Álvarez, A.; Martin, A.; Estakhri, C. Internal Structure of compacted permeable friction course mixtures. Constr. Build. Mater. 2010, 24, 1027-1035.

18. Chandrappa, A.K.; Biligiri, K.P. Pervious concrete as a sustainable pavement material-research findings and future prospects: A state-of-the-art review. Constr. Build. Mater. 2016, 111, 262-274, doi:10.1016/j.conbuildmat.2016.02.054.

19. Hasan, M.R.; Zain, M.F.M.; Hamid, R.; Kaish, A.B.M.A.; Nahar, S. A Comprehensive Study on Sustainable Photocatalytic Pervious Concrete for Storm Water Pollution Mitigation: A Review. Mater. Today Proc. 2017, 4, 9773-9776, doi:10.1016/j.matpr.2017.06.265.

20. Ballari, M.M.; Hunger, M.; Hüsken, G.; Brouwers, H.J.H. Modelling and experimental study of the NOx photocatalytic degradation employing concrete pavement with titanium dioxide. Catal. Today 2010, 151, 71-76, doi:10.1016/j.cattod.2010.03.042.

21. Karlessi, T.; Santamouris, M.; Apostolakis, K.; Synnefa, A.; Livada, I. Development and testing of thermochromic coatings for buildings and urban structures. Sol. Energy 2009, 83, 538-551, doi:10.1016/j.solener.2008.10.005.

22. Kondo, Y.; Ogasawara, T.; Kanamori, H. Field Measurements and Heat Budget Analysis on Sensible Heat Flux from Pavement. J. Environ. Eng. AIJ 2008, 73, 791-797, doi:10.3130/aije.73.791.

23. American Concrete Institute ACI Committee 522. 522R-06: Pervious Concrete; American Concrete Institute: Farmington Hills, MI, USA, 2006; p. 25.

24. Jafari, K.; Toufigh, V. Interface between Tire and Pavement. J. Mater. Civ. Eng. 2009, 29, 1-10, doi:10.1061/(ASCE)MT.1943-5533.0001963.

25. Eriskin, E.; Karahancer, S.; Terzi, S.; Saltan, M.; Examination of the Effect of Superhydrophobic Coated Pavement under Wet Conditions. Procedia Eng. 2017, 187, 532-537, doi:10.1016/j.proeng.2017.04.411.

26. Kim, Y.J.; Gaddafi, A.; Yoshitake, I. Permeable concrete mixed with various admixtures. Mater. Des. 2016, 100, 110-119, doi:10.1016/j.matdes.2016.03.109.

27. Jato-espino, D.; Rodriguez-hernandez, J.; Andrés-valeri, V.C.; Ballester-muñoz, F.; A fuzzy stochastic multi-criteria model for the selection of urban pervious pavements. Expert Syst. Appl. 2014, 41, 6807-6817, doi:10.1016/j.eswa.2014.05.008.

28. Bobylev, N.; Comparative analysis of environmental impacts of selected underground construction technologies using the analytic network process. Autom. Constr. 2011, 20, 1030-1040, doi:10.1016/j.autcon.2011.04.004. 
29. Ozbek, A.S.A.; Weerheijm, J.; Schlangen, E.; van Breugel, K. Dynamic behavior of porous concretes under drop weight impact testing. Cem. Concr. Compos. 2013, 39, 1-11, doi:10.1016/j.cemconcomp.2013.03.012.

30. Bonicelli, A.; Giustozzi, F.; Crispino, M. Experimental study on the effects of fine sand addition on differentially compacted pervious concrete. Constr. Build. Mater. 2015, 91, 102-110, doi:10.1016/j.conbuildmat.2015.05.012. (CC BY) license (http://creativecommons.org/licenses/by/4.0/). 